\title{
The relationship between anti-C-reactive protein and disease activity in patients with systemic lupus erythematosus
}

\author{
Chang-Nam Son ${ }^{1,2,}{ }^{\star}$, Tae-Han Lee ${ }^{1,}$, Ji-Hye Bang ${ }^{1}$, Hye-Jin Jeong $^{1}$, Jin-Nyeong Chae ${ }^{1}$, Won-Mok Lee ${ }^{3}$, \\ Ji-Min $\mathrm{Kim}^{1,2}$, and Sang-Hyon Kim ${ }^{1,2}$
}

\begin{abstract}
${ }^{1}$ Division of Rheumatology, Department of Internal Medicine, Keimyung University School of Medicine, Daegu; ${ }^{2}$ Institute for Medical Science, Keimyung University, Daegu; ${ }^{3}$ Department of Laboratory Medicine, Keimyung University School of Medicine, Daegu, Korea
\end{abstract}

Received: February 15, 2016 Revised : April 11, 2016

Accepted: May 3, 2016

\section{Correspondence to}

Sang-Hyon Kim, M.D.

Division of Rheumatology,

Department of Internal

Medicine, Keimyung University

School of Medicine, 56 Dalseong-

ro, Jung-gu, Daegu 41931, Korea

Tel: +82-53-250-8038

Fax: $+82-53-250-7434$

E-mail: mdkim9111@hanmail.net

*'These authors contributed equally to this work.
Background/Aims: Anti-C-reactive protein (CRP) antibody has been introduced as a potential biologic marker in Systemic lupus erythematosus (SLE). The aim of study is to evaluate the level of anti-CRP antibody in patients with SLE.

Methods: This study investigated the relationship between levels of anti-CRP antibodies and disease activity markers, such as complement, anti-double-stranded DNA antibody, and SLE disease activity index in 34 patients with SLE.

Results: The serum anti-CRP antibody levels of the patients with SLE were significantly higher than those of the healthy controls $(11.3 \pm 5.6 \mu \mathrm{g} / \mathrm{mL}$ vs. $9.1 \pm 2.8$ $\mu \mathrm{g} / \mathrm{mL}$ ). The percentages of the positive anti-CRP antibody were $52.9 \%$ in SLE and $27.8 \%$ in controls. Disease duration of SLE showed significant correlation with the anti-CRP antibody $(r=0.234, p=0.026)$. However no significant relationship was observed between the levels of anti-CRP antibodies and disease activity markers.

Conclusions: These data show that the anti-CRP antibody levels of the patients with SLE were significantly higher than those of healthy controls. We observed that the presence of the anti-CRP anti-CRP antibody was not associated with disease activity of SLE.

Keywords: Systemic lupus erythematosus; Anti-C-reactive protein antibody

\section{INTRODUCTION}

Systemic lupus erythematosus (SLE) is a chronic autoimmune disease that involves several organs and manifests diverse clinical symptoms [1]. In lupus, autoimmune antibody produced by abnormal immune responses binds with the antigen to form an immune complex, which causes damage to internal organs [2]. Many studies have reported correlation between the clinical significance of autoimmune antibodies and the disease. In particular, the lupus nephritis and its disease activity level criti- cally affect the treatment course and patient prognosis. However, only few studies have reported on anti-C-reactive protein (CRP) antibody levels in Korean patients with lupus. In one study conducted by Jung et al. [3] in which 99 lupus patients and 48 controls were compared, anti-CRP antibody levels did not significantly correlate with disease activity or the development of lupus nephritis, although the levels significantly differed between the groups. Previous studies conducted in other countries have reported that anti-CRP antibody level is associated with disease activity level and critically associ- 
ated with the prediction, treatment response evaluation, and prognosis of the morbidity of lupus nephritis [4-8]. Therefore, in this study, we aimed to examine the relationship of anti-CRP antibody level with disease activity and clinical manifestations in Korean patients with SLE.

\section{METHODS}

\section{Subjects and methods}

The study subjects included 34 lupus patients treated at the Division of Rheumatology of Keimyung University Dongsan Medical Center between March and November 2014. All the patients met the lupus classification criteria of the American College of Rheumatology, revised in 1997 [9], and lupus nephritis was defined according to the World Health Organization (WHO) classification of the condition [10]. We also recruited 36 age- and sex-matched healthy subjects as the control group. The study was approved by the Keimyung University Dongsan Medical Center Medical Research Ethics Committee (IRB 2013-12-009). Written informed consent was obtained from all participants and confirmed by the board.

During their outpatient visits, all the patients underwent testing for serum anti-CRP antibodies, complete blood count, CRP, complement $3\left(\mathrm{C}_{3}\right)$, complement 4 (C4), anti-double-stranded DNA (anti-dsDNA) antibodies, and urine. In addition, the systemic lupus erythematosus disease activity index (SLEDAI) was assessed.

\section{Measurement of serum levels of anti-CRP antibodies}

The serum levels of anti-CRP antibodies were measured by using enzyme-linked immunosorbent assay (ELISA). Capillary blood samples were obtained from both the patients and the controls, and immediately processed in a centrifugal separator at $120,000 \mathrm{rpm}$ for 20 minutes. Only the separated sera were stored in a freezer at $-70^{\circ} \mathrm{C}$ until measurement of serum anti-CRP antibody levels. Anti-CRP antibody level was measured by using an anti-CRP antibody ELISA kit (Cloud-Clone Corp., Houston, TX, USA). Before measurement, each specimen was diluted to the ratio of 1:10o in phosphate-buffered saline and cultured at $37^{\circ} \mathrm{C}$ for 2 hours after batches of $100-\mu \mathrm{L}$ specimen were transferred by using a pipette to a 96well microtiter plate. After washing with wash buffer, color reaction was induced at $37^{\circ} \mathrm{C}$ for 25 minutes by the addition of substrate solution and then stopped by the addition of a stop solution. An ELISA reader (VICTOR3, PerkinElmer Inc., Waltham, MA, USA) was used to measure optical density (OD). The obtained OD was calculated with a standard curve generated through a serial dilution of $\operatorname{serum}\left(r^{2}=0.998\right)$. The cutoff value was set as the mean $\mathrm{OD}+2 \mathrm{SD}$ of the healthy controls.

\section{Statistical analysis}

Data handling and statistical analysis were performed by using SPSS version 18.o (SPSS Inc., Chicago, IL, USA). Results are presented herein as mean \pm standard deviation. Anti-CRP antibody levels were compared between the patient and control groups by using the non-parametric Mann-Whitney $U$ test. The correlation between anti-CRP antibody level and the indicators of disease activity of lupus nephritis was examined by computing a non-parametric correlation coefficient for ordinal variables (Spearman's rho). Statistical significance was determined if the $p$ value was $<0.05$.

\section{RESULTS}

Of the 34 patients, three were male and 31 were female. The mean age was $38.5 \pm 12.28$ years, and the mean illness duration was $72.64 \pm 56.11$ months. Renal biopsy was performed for five patients (14.7\%), of whom one had class II disease and four had class IV disease according to the WHO classification criteria. The patients with lupus nephritis were only five, so we could not analyzed anti-CRP antibody according to lupus nephritis. Laboratory examination yielded the following values: leukocytes, 5,638.8 $\pm 2,635.0 / \mu \mathrm{L}$; hemoglobin, $12.1 \pm 2.0 \mathrm{~g} / \mathrm{dL}$; platelets, $230.3 \pm 88.8 \times 10^{3} / \mu \mathrm{L}$; erythrocyte sedimentation rate, 26.3 $\pm 25.5 \mathrm{~mm} / \mathrm{hr}$; CRP, $0.4 \pm 0.9 \mathrm{mg} / \mathrm{dL} ; \mathrm{C}_{3}, 83.1 \pm 28.5 \mathrm{mg} / \mathrm{dL}$; C4, $16.3 \pm 7.0 \mathrm{mg} / \mathrm{dL}$; and anti-dsDNA antibodies, $45.6 \pm$ 141.1 U/mL. The SLEDAI was $6.5 \pm 8.8$ (Table 1).

The anti-CRP antibody level was $11.3 \pm 5.6 \mu \mathrm{g} / \mathrm{mL}$ in the patient group and $9.1 \pm 2.8 \mu \mathrm{g} / \mathrm{mL}$ in the control group, demonstrating a higher level in the patient group $(p=$ 0.043) (Fig. 1). The level of positive anti-CRP antibody was $8.6 \mu \mathrm{g} / \mathrm{mL}$. The percentages of the positive anti-CRP antibody were $52.9 \%$ in SLE and $27.8 \%$ in controls. The anti-CRP antibody levels, clinical characteristics, and disease activity are compared in Table 2. One variable, 
Table 1. Clinical features of the patients with SLE

\begin{tabular}{|c|c|c|}
\hline Feature & $\operatorname{SLE}(\mathrm{n}=34)$ & Healthy controls $(n=36)$ \\
\hline Age, yr & $38.24 \pm 12.47$ & $39.2 \pm 10.5$ \\
\hline Sex, female:male & $3: 31$ & $3: 33$ \\
\hline Duration of SLE, mon & $72.64 \pm 56.11$ & Not applicable \\
\hline Leukocyte, $\mu \mathrm{L}$ & $5,638.82 \pm 2,634.98$ & NA \\
\hline Hemoglobin, g/dL & $12.12 \pm 2.03$ & NA \\
\hline Platelet, $\times 10^{3} / \mu \mathrm{L}$ & $230.26 \pm 88.82$ & NA \\
\hline $\mathrm{ESR}, \mathrm{mm} / \mathrm{hr}$ & $26.32 \pm 25.49$ & NA \\
\hline $\mathrm{CRP}, \mathrm{mg} / \mathrm{dL}$ & $0.36 \pm 0.88$ & NA \\
\hline AST, U/L & $27 \cdot 42 \pm 19 \cdot 34$ & NA \\
\hline ALT, U/L & $24.19 \pm 17.18$ & NA \\
\hline BUN, mg/dL & $17.84 \pm 8.76$ & NA \\
\hline eGFR, mg/dL & $119.12 \pm 46.13$ & NA \\
\hline Urine protein/creatinine, $\mathrm{mg} / \mathrm{g}$ & $0.40 \pm 0.86$ & NA \\
\hline Complement 3, mg/dL & $83.11 \pm 28.53$ & NA \\
\hline Complement 3, mg/dL & $16.28 \pm 7.00$ & NA \\
\hline Anti-dsDNA antibody, U/mL & $45.63 \pm 141.05$ & NA \\
\hline SLEDAI & $6.53 \pm 8.81$ & Not applicable \\
\hline \multicolumn{3}{|l|}{ Clinical manifestations } \\
\hline Arthritis & $17.6(6)$ & \\
\hline Interstitial lung disease & $8.8(3)$ & \\
\hline Pulmonary arterial hypertension & $2.9(1)$ & \\
\hline Lupus nephritis & $14 \cdot 7(5)$ & \\
\hline \multicolumn{3}{|l|}{ Medications } \\
\hline NSAID & $23 \cdot 5(8)$ & \\
\hline Corticosteroid & $82.4(28)$ & \\
\hline Hydroxychloroquine & $85 \cdot 3(29)$ & \\
\hline MMF & $26.5(9)$ & \\
\hline Tacrolimus & $5.9(2)$ & \\
\hline
\end{tabular}

Values are presented as mean $\pm \mathrm{SD}$ or percentage (number).

SLE, systemic lupus erythematosus; NA, not available; ESR, erythrocyte sedimentation rate; CRP, C-reactive protein; AST, aspartate aminotransferase; ALT, alanine aminotransferase; BUN, blood urea nitrogen; eGFR, estimated glomerular filtration rate; dsDNA, double-stranded DNA; SLEDAI, systemic lupus erythematosus disease activity index; NSAID, nonsteroidal anti-inflammatory drug; MMF, mycophenolate mofetil.

disease duration of SLE, showed significant correlation with the anti-CRP antibody $(r=0.234, p=0.026)$. However, no significant correlations were observed with complements, anti-dsDNA antibodies, SLEDAI score, and other variables. The patients were divided into two subgroups according to disease activity level, and the effect of each anti-CRP antibody was examined. However, no significant differences were found. The subgroups also did not show significant differences in, for example, blood test results, symptoms, and use of medications (Table 3). We also evaluated between anti-CRP positive patients $(n=18)$ and anti-CRP negative patients $(n=16)$. However there was no statistically different variable between groups (data not shown). 


\section{DISCUSSION}

The level of CRP is rarely high in patients with SLE, even in increased disease activity levels. If a patient with SLE has increased CRP level, other causes are considered first [11,12]. Modest elevation of CRP levels in SLE seems to be associated with elimination by autoantibodies [13-16]. Several studies have reported that anti-CRP antibody level correlated with disease activity and the occurrence of lupus nephritis. Specifically, Sjowall et al. [7] showed in a study in which 10 lupus patients were

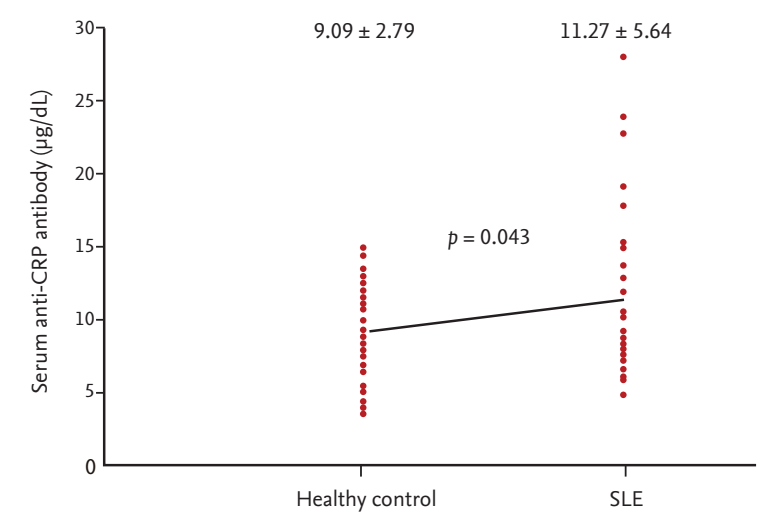

Figure 1. Serum anti-C-reactive protein (CRP) antibody levels in patients with systemic lupus erythematosus (SLE) and healthy control. followed up over time that the anti-CRP antibody level varied depending on disease activity level. In particular, the anti-CRP antibody level increased when the disease activity level of lupus nephritis increased. However, in the present study, we did not find a significant correlation between the levels of anti-CRP antibodies and disease activity markers such as complements, anti-dsDNA antibodies, and SLEDAI score. Moreover, the anti-CRP antibody levels did not differ between the patients with and those without co-occurring lupus nephritis. We believe that one reason why we did not find any significant correlation with disease activity or the occurrence of lupus nephritis in our study, unlike in other studies, may be related to the low disease activity levels of lupus in our patients. The mean levels of the complements in the 34 patients were $83.1 \pm 28.5 \mathrm{mg} / \mathrm{dL}$ for $\mathrm{C}_{3}$ and $16.3 \pm$ $7.0 \mathrm{mg} / \mathrm{dL}$ for $\mathrm{C} 4$. The mean SLEDAI was $6.5 \pm 8.8$. Only five patients had co-occurring lupus nephritis. As mentioned earlier, anti-CRP antibody levels can change depending on disease activity levels. Furthermore, in patients with lupus nephritis, a significant decrease in anti-CRP antibody level was observed after induction therapy [7]. However, the disease activity in the patients in this study was maintained at a relatively stable level, which is probably why no significant correlation was found.

Table 2. The relationship between anti-C-reactive protein antibody level and clinical Feature

\begin{tabular}{lcc}
\hline Variable & $r$ & $p$ value \\
\hline Age & 0.103 & 0.199 \\
Disease duration, mon & 0.234 & 0.026 \\
White blood count & 0.039 & 0.372 \\
Hemoglobin & 0.140 & 0.124 \\
Platelet & -0.041 & 0.367 \\
Blood urea nitrogen & -0.092 & 0.231 \\
Creatinine & -0.024 & 0.423 \\
Erythrocyte sedimentation rate & -0.148 & 0.112 \\
C-reactive protein & -0.023 & 0.427 \\
Complement 3 & 0.159 & 0.094 \\
Complement 4 & 0.123 & 0.153 \\
Urine protein/creatinine ratio & -0.002 & 0.493 \\
Anti-dsDNA antibody & -0.059 & 0.370 \\
SLEDAI & 0.056 & 0.327 \\
\hline
\end{tabular}

dsDNA, double-stranded DNA; SLEDAI, systemic lupus erythematosus disease activity index. 
Table 3. The difference of anti-CRP antibody level according to disease activity markers, laboratory findings, and combined clinical manifestations

\begin{tabular}{|c|c|c|c|}
\hline Variable & Number & Anti-CRP antibody, $\mu \mathrm{g} / \mathrm{mL}$ & $p$ value \\
\hline \multicolumn{4}{|l|}{ SLEDAI scores } \\
\hline$\geq 6$ & 13 & 10.2 & 0.173 \\
\hline$<6$ & 21 & 13.0 & \\
\hline \multicolumn{4}{|l|}{ Complement, mg/dL } \\
\hline Low $\mathrm{C}_{3}$ & 11 & 10.6 & 0.302 \\
\hline Low $\mathrm{C}_{4}$ & 6 & 11.3 & 0.991 \\
\hline Low $\mathrm{C}_{3}$ and $\mathrm{C}_{4}$ & 6 & 11.3 & 0.991 \\
\hline Normal $\mathrm{C}_{3}$ and $\mathrm{C}_{4}$ & 23 & 11.3 & \\
\hline \multicolumn{4}{|l|}{ Anti-dsDNA antibody, U/mL } \\
\hline Increased anti-dsDNA antibody & 11 & 12.5 & 0.070 \\
\hline Normal anti-dsDNA antibody & 23 & 8.8 & \\
\hline \multicolumn{4}{|l|}{$\mathrm{ESR}, \mathrm{mm} / \mathrm{hr}$} \\
\hline Increased ESR & 15 & 10.1 & 0.306 \\
\hline Normal ESR & 19 & 12.2 & \\
\hline \multicolumn{4}{|l|}{$\mathrm{CRP}, \mathrm{mg} / \mathrm{dL}$} \\
\hline Increased CRP & 5 & 14.5 & 0.175 \\
\hline Normal CRP & 29 & 10.7 & \\
\hline \multicolumn{4}{|l|}{ Steroid, mg/day } \\
\hline Low dose steroid (PDS $\leq 7.5 \mathrm{mg} /$ day) & 22 & 10.9 & 0.228 \\
\hline High dose steroid (PDS $\geq 1 \mathrm{mg} / \mathrm{kg} /$ day) & 3 & $13 \cdot 5$ & 0.563 \\
\hline Pulse therapy (PDS $\geq 250$ mg/day) & 14 & 11.5 & 0.860 \\
\hline \multicolumn{4}{|l|}{ Combined manifestations } \\
\hline With arthritis/Without arthritis & $6 / 28$ & $9.4 / 11.7$ & 0.384 \\
\hline With ILD/Without ILD & $3 / 31$ & $17.1 / 10.7$ & 0.060 \\
\hline With PAH/Without PAH & $1 / 33$ & $15 \cdot 0 / 11.2$ & 0.506 \\
\hline
\end{tabular}

CRP, C-reactive protein; SLEDAI, systemic lupus erythematosus disease activity index; dsDNA, double-stranded DNA; ESR, erythrocyte sedimentation rate; PDS, prednisolone; ILD, interstitial lung disease; PAH, pulmonary arterial hypertension.

However, a significant correlation was found between the anti-CRP antibody levels and the mean illness duration; that is, the longer the illness duration, the higher the anti-CRP antibody level. A previous study did not find any significant difference in mean illness duration between an anti-CRP-positive group and an anti-CRP-negative group [17]. However, in the present study, illness duration did not statistically correlate with any of the disease activity markers, including complements, anti-dsDNA antibodies, SLEDAI, and proteinuria. In addition, the mean illness duration was $72.6 \pm$ 56.1 months. However, three patients who had anti-CRP antibody levels higher than the mean level had had lu- pus for 187,175 , and 167 months, respectively, all of which were greater than twice the standard deviation. Therefore, we think that the finding of significant correlation with illness duration was due to the few high values in a small sample. We recommend that prospective research studies with large patient samples be conducted for a more accurate interpretation of results.

To conclude, in the present study, we confirmed that the anti-CRP antibody levels of the patients with SLE were statistically significantly higher than those of the controls. However, unlike the findings reported in a previous research study, the level of anti-CRP antibodies was not significantly correlated with lupus disease activity. For 
further understanding of the effect of anti-CRP antibodies in patients with lupus, follow-up prospective research studies with a larger number of patients are needed.

\section{KEY MESSAGE}

1. The anti-C-reactive protein (anti-CRP) antibody levels of the patients with systemic lupus erythematosus were statistically significantly higher than those of the healthy controls.

2. The level of anti-CRP antibodies was not significantly correlated with lupus disease activity.

\section{Conflict of interest}

No potential conflict of interest relevant to this article was reported.

\section{REFERENCES}

1. Sherer Y, Gorstein A, Fritzler MJ, Shoenfeld Y. Autoantibody explosion in systemic lupus erythematosus: more than 100 different antibodies found in SLE patients. Semin Arthritis Rheum 2004;34:501-537.

2. Tan EM. Antinuclear antibodies: diagnostic markers for autoimmune diseases and probes for cell biology. Adv Immunol 1989;44:93-151.

3. Jung JY, Koh BR, Kim HA, Jeon JY, Suh CH. Autoantibodies to C-reactive protein in incomplete lupus and systemic lupus erythematosus. J Investig Med 2014;62:890-893.

4. Zuniga R, Markowitz GS, Arkachaisri T, Imperatore EA, D'Agati VD, Salmon JE. Identification of IgG subclasses and C-reactive protein in lupus nephritis: the relationship between the composition of immune deposits and FCgamma receptor type IIA alleles. Arthritis Rheum 2003;48:460-470.

5. Sjowall C, Bengtsson AA, Sturfelt G, Skogh T. Serum levels of autoantibodies against monomeric C-reactive protein are correlated with disease activity in systemic lupus erythematosus. Arthritis Res Ther 2004;6;R87-R94.

6. Tan Y, Yu F, Yang H, Chen M, Fang Q, Zhao MH. Autoantibodies against monomeric $\mathrm{C}$-reactive protein in sera from patients with lupus nephritis are associated with disease activity and renal tubulointerstitial lesions. Hum Immunol 2008;69:840-844.

7. Sjowall C, Zickert A, Skogh T, Wettero J, Gunnarsson I. Serum levels of autoantibodies against C-reactive protein correlate with renal disease activity and response to therapy in lupus nephritis. Arthritis Res Ther 2009;11:R188.

8. O’Neill SG, Giles I, Lambrianides A, et al. Antibodies to apolipoprotein A-I, high-density lipoprotein, and C-reactive protein are associated with disease activity in patients with systemic lupus erythematosus. Arthritis Rheum 2010;62:845-854.

9. Hochberg MC. Updating the American College of Rheumatology revised criteria for the classification of systemic lupus erythematosus. Arthritis Rheum 1997;40:1725.

10. Weening JJ, D'Agati VD, Schwartz MM, et al. The classification of glomerulonephritis in systemic lupus erythematosus revisited. J Am Soc Nephrol 2004;15:241-250.

11. Suh CH, Chun HY, Ye YM, Park HS. Unresponsiveness of C-reactive protein in the non-infectious inflammation of systemic lupus erythematosus is associated with interleukin 6. Clin Immunol 2006;119:291-296.

12. Suh CH, Jeong YS, Park HC, et al. Risk factors for infection and role of C-reactive protein in Korean patients with systemic lupus erythematosus. Clin Exp Rheumatol 2001;19:191-194.

13. Sjowall C, Eriksson P, Almer S, Skogh T. Autoantibodies to C-reactive protein is a common finding in SLE, but not in primary Sjogren's syndrome, rheumatoid arthritis or inflammatory bowel disease. J Autoimmun 2002;19:155160.

14. Rosenau BJ, Schur PH. Antibodies to $\mathrm{C}$ reactive protein. Ann Rheum Dis 2006;65:674-676.

15. Shoenfeld Y, Szyper-Kravitz M, Witte T, et al. Autoantibodies against protective molecules. C1q, C-reactive protein, serum amyloid $\mathrm{P}$, mannose-binding lectin, and apolipoprotein A1: prevalence in systemic lupus erythematosus. Ann N Y Acad Sci 2007;1108:227-239.

16. Meyer O. Anti-CRP antibodies in systemic lupus erythematosus. Joint Bone Spine 2010;77:384-389.

17. Pradhan V, Rajadhyaksha A, Yadav K, et al. Anti-C reactive protein antibodies in Indian patients with systemic lupus erythematosus. Indian J Nephrol 2013;23:434-437. 